\title{
The Atlanta Classification of acute pancreatitis revisited
}

\author{
T. L. Bollen ${ }^{1}$, H. C. van Santvoort ${ }^{2}$, M. G. Besselink ${ }^{2}$, M. S. van Leeuwen ${ }^{3}$, K. D. Horvath ${ }^{4}$, \\ P. C. Freeny ${ }^{5}$ and H. G. Gooszen ${ }^{2}$, on behalf of the Dutch Acute Pancreatitis Study Group \\ ${ }^{1}$ Department of Radiology, St Antonius Hospital Nieuwegein, Departments of ${ }^{2}$ Surgery and ${ }^{3}$ Radiology, University Medical Centre Utrecht, The \\ Netherlands, and Departments of ${ }^{4}$ Surgery and ${ }^{5}$ Radiology, University of Washington Medical Center, Seattle, USA \\ Correspondence to: Professor H. G. Gooszen, Department of Surgery, University Medical Centre Utrecht, HP G04.228, PO Box 85500, 3508 GA Utrecht, \\ The Netherlands (e-mail: h.gooszen@umcutrecht.nl)
}

\begin{abstract}
Background: In a complex disease such as acute pancreatitis, correct terminology and clear definitions are important. The clinically based Atlanta Classification was formulated in 1992, but in recent years it has been increasingly criticized. No formal evaluation of the use of the Atlanta definitions in the literature has ever been performed.

Methods: A Medline literature search sought studies published after 1993. Guidelines, review articles and their cross-references were reviewed to assess whether the Atlanta or alternative definitions were used.

Results: A total of 447 articles was assessed, including 12 guidelines and 82 reviews. Alternative definitions of predicted severity of acute pancreatitis, actual severity and organ failure were used in more than half of the studies. There was a large variation in the interpretation of the Atlanta definitions of local complications, especially relating to the content of peripancreatic collections.

Conclusion: The Atlanta definitions for acute pancreatitis are often used inappropriately, and alternative definitions are frequently applied. Such lack of consensus illustrates the need for a revision of the Atlanta Classification.
\end{abstract}

Presented to a joint meeting of the American Pancreatic Association and the International Association of Pancreatology, Chicago, Illinois, USA, November 2006 and published in abstract form as Pancreas 2006; 33: 448-449

Paper accepted 14 July 2007

Published online 5 November 2007 in Wiley InterScience (www.bjs.co.uk). DOI: 10.1002/bjs.6010

\section{Introduction}

Over the past five decades, several classification systems on pancreatitis have emerged from interdisciplinary symposia $^{1-4}$. The most recent international meeting on this topic, the 1992 Atlanta symposium, produced a clinically based classification system ${ }^{4,5}$. Definitions of acute pancreatitis, its severity, organ failure and the local complications 'acute fluid collection', 'pancreatic necrosis', 'pseudocyst' and 'pancreatic abscess' were proposed. The Atlanta Classification attempted to introduce uniformity in the assessment of clinical severity and the various complications of the disease. This is the only widely accepted classification system used by clinicians and radiologists.

The Editors have satisfied themselves that all authors have contributed significantly to this publication
With increasing knowledge of the pathophysiology of pancreatitis and the development of new means of intervention, several authors have pointed out shortcomings in the Atlanta Classification ${ }^{6-13}$. A recent review demonstrated that terminology abandoned by the Atlanta symposium, for instance 'phlegmon' and 'infected pseudocyst', is still used frequently in the literature, and that various new terms, such as 'organized pancreatic necrosis' and 'necroma', have been introduced since $1993^{14}$. A critical evaluation of the use of the Atlanta Classification in the literature has never been performed. The present review assesses whether the definitions of the Atlanta Classification are accepted in the literature and evaluates the extent of variation in interpretation of these definitions.

\section{Methods}

A Medline search of literature published between 1993 and 2006 was performed using the following terms: 
Table 1 Summary of the 1992 Atlanta Classification

\begin{tabular}{|c|c|}
\hline & Definition \\
\hline \multirow[t]{2}{*}{ Acute pancreatitis } & $\begin{array}{l}\text { An acute inflammatory process of the pancreas with variable involvement of other regional } \\
\text { tissues or remote organ systems }\end{array}$ \\
\hline & Associated with raised pancreatic enzyme levels in blood and/or urine \\
\hline \multicolumn{2}{|r|}{ 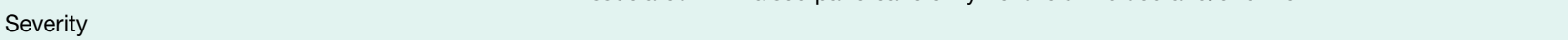 } \\
\hline Mild acute pancreatitis & $\begin{array}{l}\text { Associated with minimal organ dysfunction and an uneventful recovery; lacks the features of } \\
\text { severe acute pancreatitis. Usually normal enhancement of pancreatic parenchyma on } \\
\text { contrast-enhanced computed tomography }\end{array}$ \\
\hline Severe acute pancreatitis & $\begin{array}{l}\text { Associated with organ failure and/or local complications such as necrosis, abscess or } \\
\text { pseudocyst }\end{array}$ \\
\hline Predicted severity & Ranson score $\geq 3$ or APACHE II score $\geq 8$ \\
\hline \multicolumn{2}{|l|}{ Organ failure and systemic complications } \\
\hline Shock & Systolic blood pressure $<90 \mathrm{mmHg}$ \\
\hline Pulmonary insufficiency & $\mathrm{PaO}_{2} \leq 60 \mathrm{mmHg}$ \\
\hline Renal failure & Creatinine $\geq 177 \mu \mathrm{mol} / \mathrm{l}$ or $\leq 2 \mathrm{mg} / \mathrm{dl}$ after rehydration \\
\hline Gastrointestinal bleeding & $500 \mathrm{ml}$ in $24 \mathrm{~h}$ \\
\hline Disseminated intravascular coagulation & Platelets $\leq 100,000 / \mathrm{mm}^{3}$, fibrinogen $<1.0 \mathrm{~g} / \mathrm{l}$ and fibrin-split products $>80 \mu \mathrm{g} / \mathrm{l}$ \\
\hline Severe metabolic disturbances & Calcium $\leq 1.87 \mathrm{mmol} / \mathrm{l}$ or $\leq 7.5 \mathrm{mg} / \mathrm{dl}$ \\
\hline \multicolumn{2}{|l|}{ Local complications } \\
\hline Acute fluid collections & $\begin{array}{l}\text { Occur early in the course of acute pancreatitis, are located in or near the pancreas and always } \\
\text { lack a wall of granulation of fibrous tissue. In about half of patients, spontaneous regression } \\
\text { occurs. In the other half, an acute fluid collection develops into a pancreatic abscess or } \\
\text { pseudocyst }\end{array}$ \\
\hline \multirow[t]{2}{*}{ Pancreatic necrosis } & $\begin{array}{l}\text { Diffuse or focal area(s) of non-viable pancreatic parenchyma, typically associated with } \\
\text { peripancreatic fat necrosis }\end{array}$ \\
\hline & $\begin{array}{l}\text { Non-enhanced pancreatic parenchyma }>3 \mathrm{~cm} \text { or involving more than } 30 \% \text { of the area of the } \\
\text { pancreas }\end{array}$ \\
\hline Acute pseudocyst & $\begin{array}{l}\text { Collection of pancreatic juice enclosed by a wall of fibrous or granulation tissue, which arises as } \\
\text { a result of acute pancreatitis, pancreatic trauma or chronic pancreatitis, occurring at least } 4 \\
\text { weeks after onset of symptoms, is round or ovoid and most often sterile; when pus is present, } \\
\text { lesion is termed a 'pancreatic abscess' }\end{array}$ \\
\hline \multirow[t]{3}{*}{ Pancreatic abscess } & $\begin{array}{l}\text { Circumscribed, intra-abdominal collection of pus, usually in proximity to the pancreas, } \\
\text { containing little or no pancreatic necrosis, which arises as a consequence of acute } \\
\text { pancreatitis or pancreatic trauma }\end{array}$ \\
\hline & Often 4 weeks or more after onset \\
\hline & $\begin{array}{l}\text { Pancreatic abscess and infected pancreatic necrosis differ in clinical expression and extent of } \\
\text { associated necrosis }\end{array}$ \\
\hline
\end{tabular}

APACHE, Acute Physiology And Chronic Health Evaluation; $\mathrm{PaO}_{2}$, arterial partial pressure of oxygen.

'acute pancreatitis and review' and 'acute pancreatitis and guidelines'. From the identified guidelines and reviews, cross-references were retrieved. The search included all types of publication (reviews, guidelines, original studies, case reports and editorials), but excluded those not in English and animal experimental studies. One author (T.L.B.) performed the selection and reviewed all full-text papers to assess whether the original Atlanta definitions (Table 1) or other definitions were used for the following five components of the Atlanta Classification: diagnosis (cut-off levels of pancreatic enzymes lipase and amylase); predicted severity (predictive scoring systems, cut-off levels of scoring systems); actual severity (distinction between mild and severe pancreatitis, distinction between predicted and actual severity); organ failure (determinants of individual failing organ systems, cut-off levels of determinants, distinction between single-organ failure and multiorgan failure); local complications (pancreatic necrosis and peripancreatic necrosis, infection of necrosis, morphological aspects and distinction of different types of collection).

If different definitions for the components were identified, this was double checked by one of two other authors (H.C.v.S., M.G.B.). All disagreements were resolved by discussion among the authors. In addition, study results leading to new insights that might have influenced the interpretation of the Atlanta Classification were recorded and are discussed. As a large number of references were retrieved, for each component of the Atlanta Classification that was assessed only the three most recent articles are cited here; the remaining references are published in Appendix 1 (available as supplementary material online at www.bjs.co.uk). 


\section{Results}

A total of 447 articles was reviewed, including 12 guidelines and 82 reviews. These articles reported on studies that were not specifically designed to evaluate the Atlanta Classification; they merely mentioned Atlanta definitions (for example a randomized trial comparing two treatment strategies with the outcome 'pseudocyst'). Therefore, an assessment of methodological quality was deemed inappropriate. Table 2 gives an overview of the papers according to type of article and impact factor of the journals in which they were published. The most important discrepancies for the five components of the Atlanta Classification and discrepancies in the 12 guidelines are discussed in order.

\section{Diagnosis}

The Atlanta Classification provides no cut-off value for pancreatic enzyme levels. In 116 studies, the diagnosis of acute pancreatitis was defined as a characteristic clinical history of abdominal pain and an increased level of pancreatic enzymes to three or more times the upper limit of normal. However, 31 studies used different thresholds, ranging from two or more ${ }^{15-17}$ to more than four ${ }^{18-20}$ and more than five $e^{21-23}$ times the upper limit of normal.

\section{Predicted severity}

A total of 283 articles provided criteria for predicting severity in acute pancreatitis. Some 86 reports used the severity scoring systems proposed by the Atlanta symposium ${ }^{16,17,23}$. However, 197 studies used a different cut-off level for defining severity, or used different or additional scoring systems, such as computed tomography (CT) severity index, Imrie (Glasgow) score, Simplified Acute Physiology score, Sequential Organ Failure Assessment or severity predictors (such as C-reactive protein) ${ }^{15,24,25}$. Cut-off values for severity stratification differed considerably between reports. For the CT severity index, the most established radiological scoring system developed by Balthazar and colleagues $^{26}$ in 1990, the cut-off value to differentiate between mild and severe disease ranged from three or more to eight or more points ${ }^{27-29}$. In 32 studies, threshold values for Acute Physiology And Chronic Health Evaluation (APACHE) II score (other than eight or more) varied from five or more to 11 or more, whereas the time for calculating the score varied from day of admission to 24 and $48 \mathrm{~h}$ after admission ${ }^{30-32}$. Eleven studies used different threshold values for the Ranson criteria (other than three or more), ranging from more than three to more than five $e^{32-34}$.

Since the Atlanta symposium in 1992, many studies have identified new predictors of severity and these have been incorporated in several guidelines. Such predictors include age (over $55^{6}$, over $70^{35}$ or over $80^{36}$ years), obesity (body mass index over $\left.30 \mathrm{~kg} / \mathrm{m}^{2}\right)^{11,24,37}$, pleural effusion (left or bilateral) on chest radiograph ${ }^{38-40}$, raised haematocrit level ${ }^{6,41,42}$ and C-reactive protein level greater than $150 \mathrm{mg} / \mathrm{dl}$ after $48 \mathrm{~h}^{43-45}$.

\section{Actual severity}

Of 297 articles providing definitions for severe acute pancreatitis, 195 defined severe disease according to the Atlanta Classification, although 61 merely stated that the Atlanta criteria were used without specification ${ }^{46-48}$. The remaining 102 articles used definitions of severe disease other than those of the Atlanta Classification. These definitions were based on admission to an intensive care unit, length of intensive care unit or hospital stay, complications requiring medical or operative intervention, mortality or various other, additional or non-specified criteria ${ }^{17,49,50}$. The authors of 45 articles used the absence and presence of

Table 2 Characteristics of retrieved articles (1993-2006) specified according to impact factor of journal

\begin{tabular}{|c|c|c|c|c|}
\hline & \multirow[b]{2}{*}{$\begin{array}{l}\text { Total no. } \\
\text { of studies } \\
(n=447)\end{array}$} & \multicolumn{3}{|c|}{ Impact factor } \\
\hline & & $\begin{array}{l}\text { High }(>5.0) \\
\quad(n=89)\end{array}$ & $\begin{array}{l}\text { Intermediate }(1.5-4.9) \\
\qquad(n=273)\end{array}$ & $\begin{array}{c}\text { Low }(<1.5) \\
\quad(n=85)\end{array}$ \\
\hline Meta-analyses & 3 & 2 & 1 & 0 \\
\hline Randomized controlled trials & 34 & 13 & 18 & 3 \\
\hline Prospective series & 144 & 28 & 99 & 17 \\
\hline Retrospective series & 147 & 23 & 95 & 29 \\
\hline Reviews & 82 & 10 & 44 & 28 \\
\hline Guidelines & 12 & 5 & 5 & 2 \\
\hline Editorials & 5 & 2 & 3 & 0 \\
\hline Other & 20 & 6 & 8 & 6 \\
\hline
\end{tabular}


pancreatic necrosis broadly synonymously with mild and severe acute pancreatitis respectively $47,51,52$. Some reports, however, pointed out that patients with the morphological diagnosis of interstitial pancreatitis may develop clinically severe disease ${ }^{44,53,54}$.

The relationship between the development of organ failure and pancreatic necrosis (the most important determinants of severe acute pancreatitis) is contentious. Several reports noted that only $51-55$ per cent of patients with pancreatic necrosis manifested organ failure ${ }^{55-57}$. In the study by Lankisch and colleagues ${ }^{53}, 15$ per cent of patients with acute oedematous pancreatitis developed organ failure. In a recent study, organ failure was the main risk factor for mortality, regardless of the presence or absence of pancreatic necrosis ${ }^{23}$. Conversely, other studies showed a good correlation between organ failure and the extent of pancreatic necrosis ${ }^{16,58,59}$.

Finally, in 38 articles, the differentiation between 'predicted severe' acute pancreatitis (Ranson, Imrie or APACHE II score) and 'actual severe' disease (systemic or local complications) was not apparent from the published data ${ }^{17,28,60}$. The difference is important, because in recent studies less than 50 per cent of patients with predicted severe disease eventually turned out to have actual severe disease according to the Atlanta criteria ${ }^{25,46}$. This lack of distinction may account for the variation in incidence of severe acute pancreatitis among institutions.

\section{Organ failure}

Criteria for organ failure were found in 149 articles. In 35 reports the exact Atlanta definitions for organ failure were specifically stated and used ${ }^{23,61,62}$. Seven articles restricted organ failure to two of the four Atlanta determinants for organ failure: respiratory and renal insufficiency ${ }^{63-65}$. However, 107 articles used additional criteria for organ failure and systemic complications, such as leucocytosis, temperature, coagulopathy, nervous system failure, hepatic failure, systemic inflammatory response syndrome or sepsis, or used altered thresholds or adjustments for the Atlanta definitions of organ failure ${ }^{52,66,67}$. The remaining articles gave no definition of organ failure, or simply noted that the Atlanta criteria were used, without specification.

In recent years, multiorgan failure has been acknowledged as a major determinant of mortality. However, no uniform definition for multiorgan failure exists: 20 reports defined it as failure of two or more organ systems s $^{31,46,49}$, and eight as failure of three or more organ systems ${ }^{23,68,69}$, although most studies did not define multiorgan failure.

The dynamic process of organ dysfunction is increasingly recognized, and several authors differentiated between transient and persistent organ failure $\mathrm{e}^{70-72}$. In addition, several studies showed that early and progressive organ failure was associated with high mortality, but most patients with transient organ failure had an uncomplicated course $^{72-74}$. The recent UK guidelines on acute pancreatitis state that organ failure in the first week resolving within 48 h should not be considered an indicator of severe disease $^{43}$.

Since 1993, several new organ failure grading systems have been developed (Goris score, Marshall or multiple organ dysfunction score, Bernard score, Sequential Organ Failure Assessment and logistic organ dysfunction syndrome score) that take into account the number of organ systems involved and the degree of dysfunction of each individual organ. Some systems also include the need for inotropic or vasopressor agents, mechanical ventilation and dialysis that the Atlanta symposium did not account for. Several studies have shown that dynamic scoring systems (such as the delta APACHE II score) or scoring systems that account for the physiological response to treatment (such as the delta organ failure score or cumulative Marshall score) are better predictors of outcome than static scoring systems $^{31,32,71}$.

\section{Local complications}

In a recent interobserver agreement study on the Atlanta definitions regarding the various local complications, interobserver agreement was poor: five radiologists agreed on the respective Atlanta definition in only three of 70 collections depicted by contrast-enhanced CT (CECT $)^{8}$.

\section{Acute fluid collection}

In 64 articles, a definition was given for an 'acute fluid collection'. The following terms were used to describe acute fluid collections: '(peri)pancreatic fluid collections ${ }^{75-77}$, 'peripancreatic effusions' ${ }^{78}$, 'extrapancreatic fluid collections' $61,79,80$, 'immature pseudocyst' and 'exudates" 54 . (Peri)pancreatic fluid collection was also used as an overall descriptive term for all types of collection related to acute pancreatitis ${ }^{83-85}$.

In most reports, the differentiation between acute fluid collection and pseudocyst was made after 4 weeks from onset of disease (as proposed by the Atlanta Classification). In eight reports, however, a different time period was used as a criterion for this distinction, varying from 3 weeks ${ }^{75,86,87}$ to $6^{88,89}$ and even $8^{90}$ weeks. Moreover, they did not adequately describe whether acute fluid collections consisted of fluid alone or whether they may have contained necrotic debris ${ }^{85,91,92}$.

Authors of 17 articles regarded the occurrence of an acute fluid collection to be a local complication and so a 


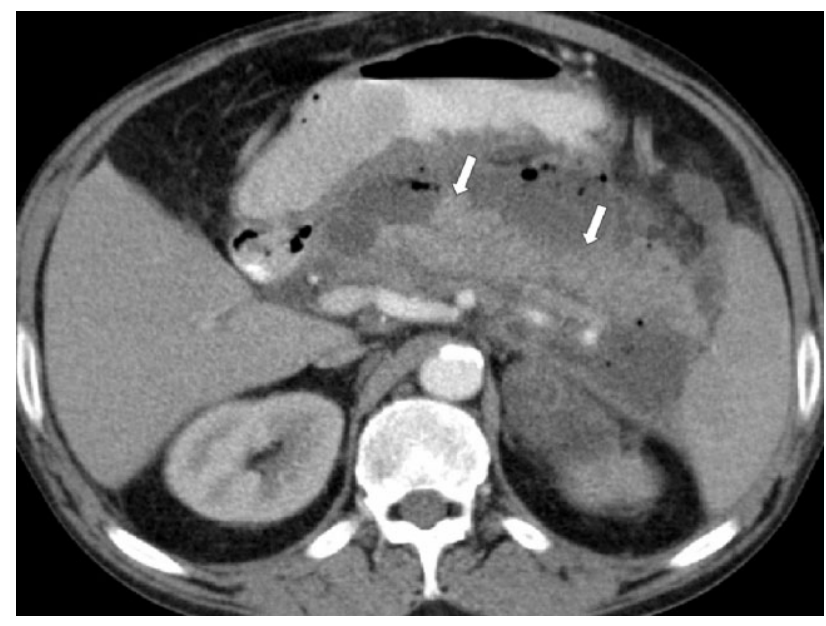

a Normal enhancement of the pancreas

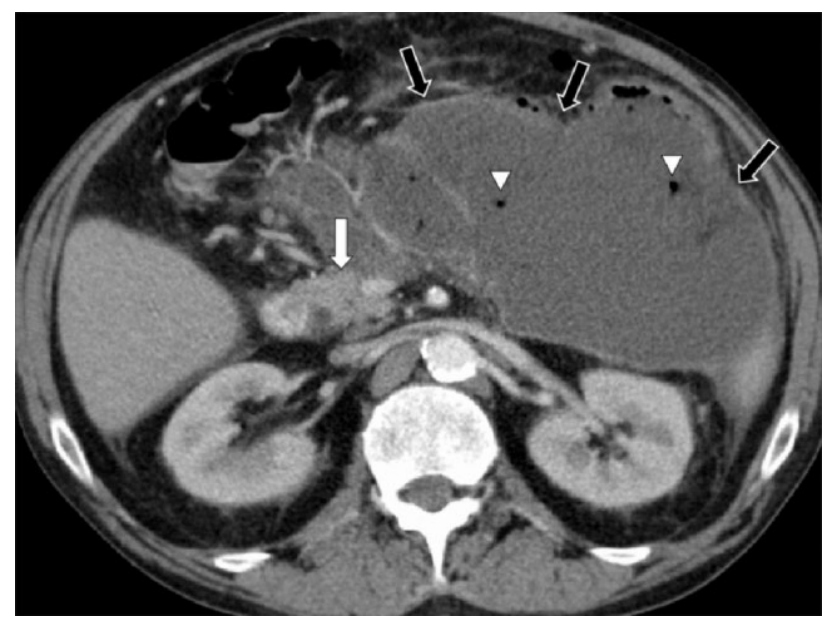

b Large fluid collection with gas bubbles

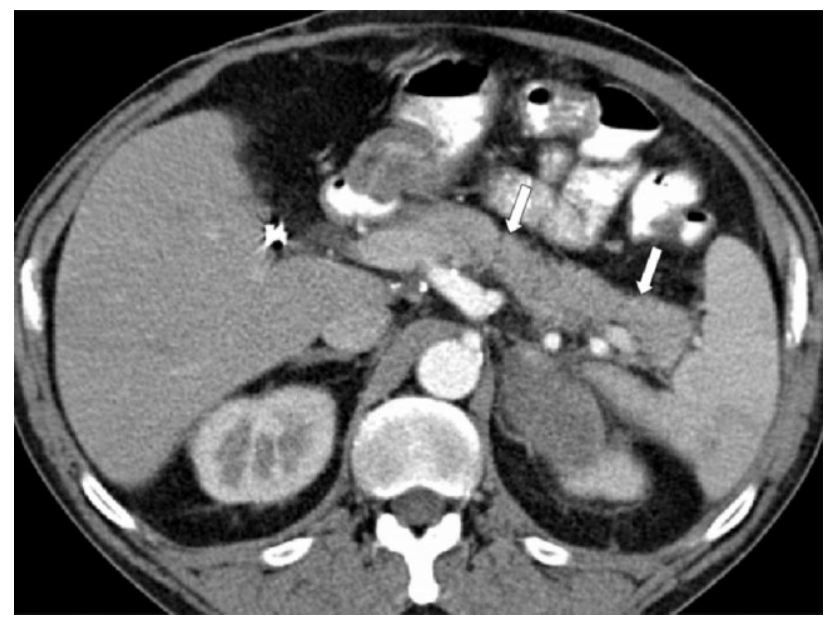

C Follow-up 6 months after operation

Fig. 1 Contrast-enhanced computed tomography (CT) of a patient with acute pancreatitis 22 days after onset of symptoms, a with normal enhancement of the pancreas (white arrows) and $\mathbf{b}$ surrounded by a large heterogeneous and encapsulated fluid collection (black arrows) with gas bubbles (arrowheads) suggesting secondary infection. Some would call this 'necrotizing pancreatitis', but others would call it 'interstitial pancreatitis' because there is no evidence of pancreatic parenchymal necrosis (only peripancreatic necrosis). A large amount of fat necrosis was debrided during operation. c Follow-up CT 6 months after operation reveals a normal enhancing pancreatic parenchyma (white arrows)

sign of 'severe disease $46,62,93$. However, most others did not include acute fluid collection either in the definition of local complication or in that of severe disease.

\section{Pancreatic necrosis}

Of 152 articles that gave a specific definition for 'pancreatic necrosis' or 'necrotizing pancreatitis' (Fig. 1), 47 used the Atlanta criterion of more than 30 per cent parenchymal necrosis to define necrotizing pancreatitis ${ }^{28,61,94}$. However, 85 defined necrotizing pancreatitis as any evidence of pancreatic parenchymal necrosis (including less than
30 per cent parenchymal necrosis) ${ }^{47,95,96}$. A third definition of necrotizing pancreatitis, reported in 20 papers, was the appearance of pancreatic necrosis or extrapancreatic necrosis, or both, on CECT (and a serum C-reactive protein value of more than $150 \mathrm{mg} / \mathrm{dl})^{52,86,97}$.

In the Atlanta Classification, the definition of pancreatic necrosis requires pancreatic parenchymal nonenhancement on $\mathrm{CECT}^{4}$. However, some clinicians questioned whether non-enhancement on CECT meant irreversible damage and necrosis ${ }^{86,98,99}$. For instance, Traverso 
and Kozarek $^{86}$ defined pancreatic necrosis as devitalized tissue found at operation. This was supported by Takeda and colleagues ${ }^{100-102}$, who noted that pancreatic parenchymal perfusion was maintained during intraarterial angiography, while CECT showed pancreatic nonenhancement. In contrast, several studies demonstrated a good correlation between parenchymal non-enhancement on CECT and the presence of pancreatic necrosis (confirmed at operation) $)^{103-105}$.

Data on the accuracy of CECT in diagnosing extrapancreatic or peripancreatic fat necrosis are conflicting. Although eight groups claimed that fat necrosis could not be determined reliably by CECT $^{92,106,107}$, several studies demonstrated a good correlation between extrapancreatic findings on CECT and the presence of fat necrosis at operation or autopsy ${ }^{104,108,109}$.

The Atlanta Classification includes both infected and sterile necrosis within the definition of 'pancreatic necrosis'4. Several groups claimed that pancreatic parenchymal necrosis without infection is not a major morbidity risk ${ }^{110-112}$. This was supported by studies showing an uncomplicated course in the presence of necrosis without infection ${ }^{23,55,56}$. Beger and colleagues ${ }^{81,113}$ were the first to emphasize that necrosis is a potential nidus for secondary infection occurring in 40-70 per cent of patients. Recent studies confirmed this, demonstrating infected necrosis as the primary cause of late mortality ${ }^{58,114,115}$. However, definitions of 'infected necrosis' were also conflicting. Some authors regarded the presence of parenchymal necrosis as a prerequisite for the diagnosis of infected necrosis ${ }^{116-118}$, but others defined infected necrosis as infection that could occur in parenchymal necrosis or peripancreatic fat necrosis (in other words, in the absence of parenchymal necrosis), or both ${ }^{67,76,119}$.

\section{Pseudocyst}

A specific definition for the term 'pseudocyst' was provided in 87 articles, and all were similar to that of the Atlanta Classification. Some controversies, however, remain. Thirty-eight articles included collections containing both fluid and necrotic debris under the heading of pseudocyst (Fig. 2) ${ }^{120-122}$. Yet Baron ${ }^{123}$ and others ${ }^{85,124}$ have stated that pseudocysts should be devoid of solid necrotic debris. Evidence has shown that therapeutic strategy and outcome differed between collections containing fluid alone and those containing necrosis and fluid ${ }^{84,125,126}$. Bradley ${ }^{127}$ considered that mischaracterization of (peri)pancreatic fluid collections as pseudocyst by CECT was an extremely common error in contemporary diagnostic radiology. This mischaracterization has two potentially dangerous consequences: first, by instrumentation of a sterile

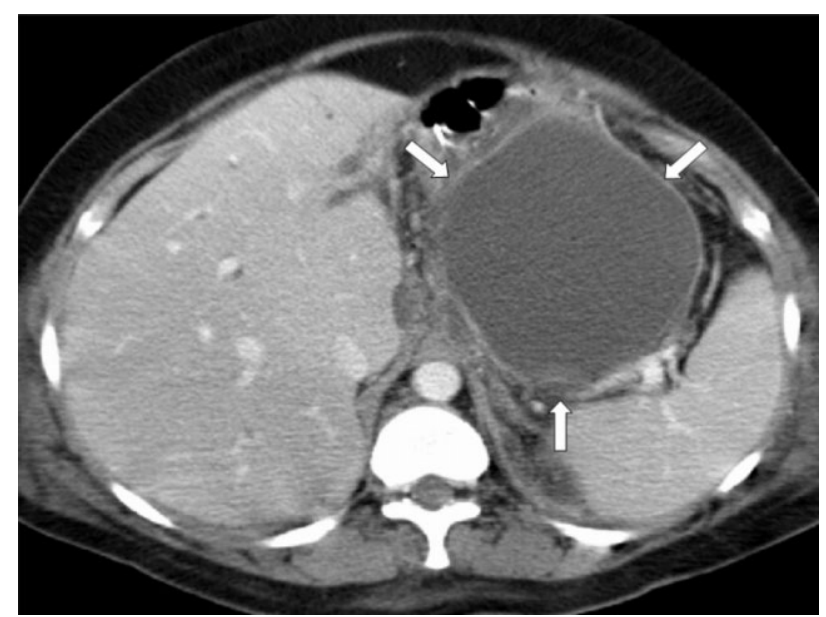

Fig. 2 Contrast-enhanced computed tomography (CT) of a patient with acute pancreatitis 30 days after onset of symptoms. The fluid collection seems to be homogeneous and encapsulated (white arrows) and could be interpreted as a 'pseudocyst' according to the Atlanta Classification. However, at operation the collection was found to contain large amounts of necrotic debris that CT had not shown

collection containing both fluid and necrosis, infection may be introduced ${ }^{6,120,128}$; second, a delay in appropriate intervention may occur ${ }^{33,120,129}$.

The incidence, natural history and options for management differed between acute and chronic pseudocysts. Several authors emphasized that the results of treatment of pancreatic fluid collections in the literature were difficult to interpret, because often no distinction was made between pseudocysts and acute fluid collections, or between pseudocysts that complicated acute and chronic pancreatitis $^{122,128,130}$. Thirty-one original articles on the treatment of pseudocysts were reviewed but only five dealt exclusively with pseudocysts after an episode of acute pancreatitis ${ }^{89,120,131}$. The remaining 26 articles reported results of the treatment of pseudocysts complicating acute and chronic pancreatitis ${ }^{121,132,133}$.

\section{Pancreatic abscess}

Some 68 articles provided a definition of 'pancreatic abscess', which was generally in line with the original Atlanta definition. Nine original articles after 1993 were identified that reported on the treatment of 'pancreatic abscesses', and the Atlanta definition (collection of pus and virtually no necrotic debris, more than 4 weeks after onset) was strictly applied in three of these ${ }^{134-136}$. The others included collections that contained, in addition to pus, solid necrotic debris ${ }^{137-139}$ or that were treated within 4 weeks of onset of disease ${ }^{140}$ or after surgery ${ }^{141,142}$. 
Table 3 Overview of definitions for organ failure and predicted severe acute pancreatitis in guidelines for acute pancreatitis published after 1993

\begin{tabular}{|c|c|c|}
\hline Guideline & Definitions for organ failure & Definitions for predicted severe acute pancreatitis \\
\hline ACG $1997^{157}$ & Refers to Atlanta Classification 1992 & $\begin{array}{l}\text { Ranson score } \geq 3 \text { after } 48 \mathrm{~h} \\
\text { APACHE II score }>8 \text { after } 48 \mathrm{~h}\end{array}$ \\
\hline UK $1998^{158}$ & Refers to Atlanta Classification 1992 & $\begin{array}{l}\text { Ranson/Glasgow } \geq 3 \\
\text { CRP }>210 \mathrm{mg} / \mathrm{l} \text { (first } 4 \text { days) or }>120 \mathrm{mg} / \mathrm{l} \text { at } 1 \text { week } \\
\text { APACHE II score } \geq 9 \text { (severe acute pancreatitis) or } \geq 6 \text { (includes all } \\
\text { severe cases, but PPV of } 50 \% \text { ) }\end{array}$ \\
\hline SSAT $1998^{159}$ & Not addressed & Not stated \\
\hline Santorini $1999^{160}$ & Not addressed & $\begin{array}{l}\mathrm{BMI}>30 \mathrm{~kg} / \mathrm{m}^{2} \\
\text { Pleural effusion } \\
\text { APACHE II score } \geq 6 \text { (at } 24 \mathrm{~h} \text { ) } \\
\text { APACHE (obesity) score } \geq 6 \\
\text { CRP }>150 \mathrm{mg} / \mathrm{l}\end{array}$ \\
\hline French $2000^{36}$ & $\begin{array}{l}\text { Renal failure: creatinine }>170 \mu \mathrm{mol} / \mathrm{l} \\
\text { Shock: systolic } \mathrm{BP}<90 \mathrm{mmHg} \text { despite fluid } \\
\quad \text { replacement } \\
\text { Pulmonary insufficiency: } \mathrm{PaO}_{2} \leq 60 \mathrm{mmHg} \text { on } \\
\quad \text { room air } \\
\text { Glasgow Coma Score }<13 \\
\text { Platelets }<80 \mathrm{~g} / \mathrm{l}\end{array}$ & $\begin{array}{l}\text { At admission } \\
\text { Age }>80 \text { years } \\
\mathrm{BMI}>30 \mathrm{~kg} / \mathrm{m}^{2} \\
\text { Chronic renal failure } \\
\text { Pre-existing severe illnesses } \\
\text { At } 24-48 \mathrm{~h} \\
\text { Presence of organ failure by using simple measures or use of } \\
\text { scoring system (e.g. SOFA) } \\
\text { Ranson//mrie score }>3 \\
\text { CECT: CT severity index } \geq 4 \text { ( } 48-72 \mathrm{~h} \text { ) } \\
\text { CRP }>150 \mathrm{mg} / \mathrm{l} \\
\text { Note: 'The non-specific scores (APACHE II, SAP II, etc) are not } \\
\text { recommended by the Jury' }\end{array}$ \\
\hline WCG $2002^{35}$ & $\begin{array}{l}\text { SIRS } \\
\geq 1 \text { vital organ dysfunction } \\
\text { ARDS } \\
\text { Renal failure: increased serum creatinine } \\
>0.5 \mathrm{mg} / \mathrm{dl}(44 \mu \mathrm{mol} / \mathrm{l}) \text { or } 50 \% \text { above } \\
\text { baseline or reduction in calculated } \\
\text { creatinine clearance }>50 \% \text { or need for } \\
\text { dialysis } \\
\text { Hypotension: mean arterial pressure } \\
\quad<60 \mathrm{mmHg} \\
\text { DIC } \\
\text { Acute adrenal insufficiency } \\
\text { Acute hepatitis } \\
\text { Metabolic encephalopathy } \\
\text { Ileus }\end{array}$ & $\begin{array}{l}\text { At admission } \\
\text { Age }>70 \text { years } \\
\text { Clinical assessment } \\
\mathrm{BMl}>30 \mathrm{~kg} / \mathrm{m}^{2} \\
\text { Pleural effusion/infiltrates } \\
\text { CECT: }>30 \% \text { non-enhancement of the pancreas } \\
\text { APACHE II score } \geq 8 \\
\text { Presence of organ failure } \\
\text { At } 24-48 \mathrm{~h} \\
\text { Clinical assessment } \\
\text { Glasgow score (no cut-off value provided) } \\
\text { CRP }>150 \mathrm{mg} / \mathrm{l} \\
\text { Presence of organ failure }\end{array}$ \\
\hline IAP $2002^{161}$ & Not addressed & Not stated: surgical guideline \\
\hline JSAEM $2002^{162}$ & Not addressed & $\begin{array}{l}\text { Clinical signs } \\
\text { CRP ( } 48 \mathrm{~h} \text { : no cut-off value provided) } \\
\text { BMI (no value provided) } \\
\text { CECT: necrosis } \\
\text { Scoring system, like JMHW, APACHE II at } 24 \mathrm{~h} \text { or Ranson/Glasgow } \\
\text { at } 24-48 \mathrm{~h} \text { : no cut-off values provided } \\
\text { Japanese score } \geq 2\end{array}$ \\
\hline Nathens $2004^{148}$ & $\begin{array}{l}\text { Refers to the guidelines for intensive care unit } \\
\text { admission, published in } 1999^{163}\end{array}$ & $\begin{array}{l}\text { Elderly (age not specified) } \\
\text { BMI }>30 \mathrm{~kg} / \mathrm{m}^{2} \\
\text { Patients requiring ongoing volume resuscitation } \\
\text { CECT: > 30\% non-enhancement of the pancreas } \\
\text { Clinical assessment } \\
\text { Note: 'Disease-specific scoring systems or severity scores are useful } \\
\text { adjuncts to identify patients at high risk of a complication, but } \\
\text { should not replace serial clinical assessments. In addition, there is a } \\
\text { recommendation against the use of markers such as CRP or } \\
\text { procalcitonin to guide clinical decision making or predict clinical } \\
\text { course of acute pancreatitis or to triage patients' }\end{array}$ \\
\hline
\end{tabular}


Table 3 (Continued)

\begin{tabular}{|c|c|c|}
\hline Guideline & Definitions for organ failure & Definitions for predicted severe acute pancreatitis \\
\hline UK $2005^{43}$ & Refers to Atlanta Classification 1992 & $\begin{array}{l}\text { At admission } \\
\text { Clinical assessment } \\
\text { BMI }>30 \mathrm{~kg} / \mathrm{m}^{2} \\
\text { Pleural effusion } \\
\text { APACHE score }>8 \\
\text { At } 24-48 \mathrm{~h} \\
\text { Clinical assessment } \\
\text { Glasgow score } \geq 3 \\
\text { APACHE II score }>8 \\
\text { Persistent organ failure for } 48 \mathrm{~h} \text { (especially if multiple and } \\
\text { progressive) } \\
\text { CRP > } 150 \text { mg/l } \\
\text { Note: 'Organ failure present within } 1 \text { week, which resolves within } 48 \\
h \text {, should not be considered an indicator of a severe attack of } \\
\text { acute pancreatitis' }\end{array}$ \\
\hline ACG $2006^{6}$ & $\begin{array}{l}\text { Refers to Atlanta classification } 1992 \\
\text { Note: 'Criteria of organ failure will change in } \\
\text { the future: gastrointestinal bleeding will } \\
\text { undoubtedly be deleted' }\end{array}$ & $\begin{array}{l}\text { At admission } \\
\text { Age }>55 \text { years } \\
\text { BMI }>30 \mathrm{~kg} / \mathrm{m}^{2} \\
\text { Presence of organ failure } \\
\text { Pleural effusion/infiltrates } \\
24-48 \mathrm{~h} \\
\text { APACHE II score } \geq 8 \\
\text { Serum haematocrit } \geq 44 \% \\
\text { Note: 'Ranson signs are no longer advocated, due to } \\
\text { a comprehensive evaluation of } 110 \text { studies that concluded that } \\
\text { Ranson signs provided very poor predictive power of severity of } \\
\text { acute pancreatitis' }\end{array}$ \\
\hline JSAEM $2006^{164,165}$ & $\begin{array}{l}\text { Pulmonary insufficiency: dyspnoea } \\
\text { Shock } \\
\text { Central nervous system disorders } \\
\text { Bleeding tendency } \\
\text { Negative base excess failure: rise of blood } \\
\text { urea nitrogen level and creatinine level }\end{array}$ & Japanese score $\geq 2$ \\
\hline
\end{tabular}

ACG, Practice Parameters Committee of the American College of Gastroenterology; APACHE, Acute Physiology And Chronic Health Evaluation; UK, Working Party of the British Society of Gastroenterology, Association of Surgeons of Great Britain and Ireland, Pancreatic Society of Great Britain and Ireland, and Association of Upper GI Surgeons of Great Britain and Ireland; CRP, C-reactive protein; PPV, positive predictive value; SSAT, Society for Surgery of the Alimentary Tract; Santorini, Santorini Consensus Conference; BMI, body mass index; French, French Consensus Conference on Acute Pancreatitis; BP, blood pressure; $\mathrm{PaO}_{2}$, arterial partial pressure of oxygen; SOFA, Sequential Organ Failure Assessment; CECT, contrast-enhanced computed tomography; SAP, Simplified Acute Physiology; WCG, World Congress of Gastroenterology; SIRS, systemic inflammatory response syndrome; ARDS, adult respiratory distress syndrome; DIC, disseminated intravascular coagulation; IAP, International Association of Pancreatology; JSAEM, Japanese Society of Emergency Abdominal Medicine; JMHW, Japanese Ministry of Health and Welfare; Nathens, Consensus Statement regarding the management of the critically ill patient with severe acute pancreatitis.

The diagnosis of pancreatic abscess on CECT is also controversial. In ten articles, the 'air bubble' phenomenon was considered 'diagnostic of a pancreatic abscess,93,143,144. In 31, however, gas bubbles in a heterogeneous collection on CT were regarded as highly indicative of infected pancreatic necrosis (Fig. 3) ${ }^{61,67,145}$. Varying hypotheses exist on the aetiology of pancreatic abscess. Some authors considered 'postacute pseudocysts' and pancreatic abscesses as late consequences of necrotizing pancreatitis $^{146-148}$. In contrast, others maintained that pancreatic abscesses occurred exclusively in interstitial pancreatitis with a normal enhancing pancreas on CECT $^{117,149,150}$.

Apart from 'infection of a pseudocyst', several authors hypothesized that pancreatic abscesses evolved from progressive liquefaction of necrotic pancreatic and peripancreatic tissues, in time resulting in complete liquefaction $76,123,151$. According to the Atlanta Classification, most pancreatic abscesses arise at least 4 weeks after onset of symptoms ${ }^{4}$, although others diagnose 'pancreatic abscesses' after $1^{50,152}, 2^{153,154}$ or $3^{86,146,147}$ weeks. Interestingly, when performing operative necrosectomy 


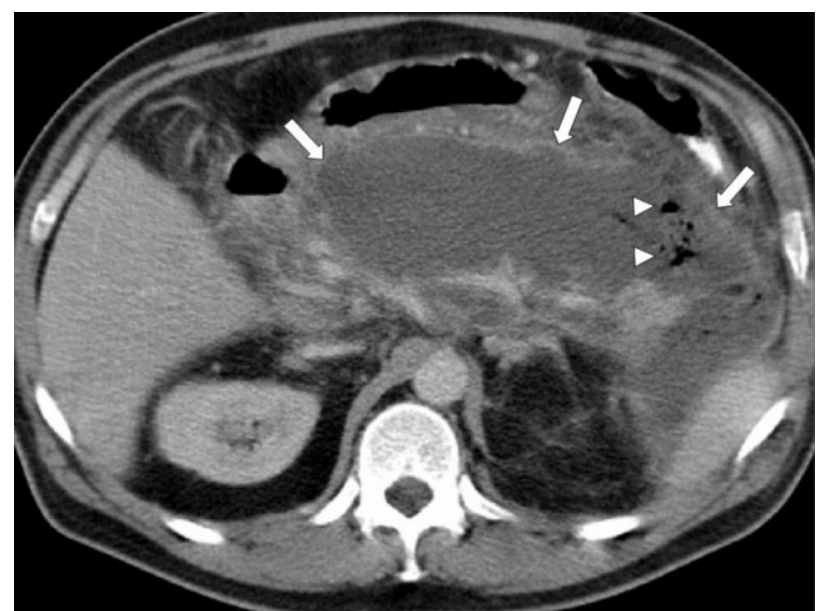

Fig. 3 Contrast-enhanced computed tomography of a patient with acute pancreatitis 36 days after onset of symptoms. The body and tail of the pancreas are largely non-enhancing. Adjacent to the pancreatic bed is a large collection with predominately fluid-like attenuation (white arrows). Because of the gas bubbles (arrowheads), some would call this a 'pancreatic abscess' but others would call it 'infected pancreatic necrosis'

several months after the onset of severe acute pancreatitis, Morgan and colleagues ${ }^{10}$, Howard and Wagner ${ }^{155}$ and others ${ }^{156}$ observed different degrees of liquefaction of necrotic tissue. Several authors acknowledged this evolving process, and they postulated that a collection may represent a transitional entity from (infected) pancreatic necrosis to an (infected) pseudocyst or pancreatic abscess, as they encountered both pus and necrotic debris in these (infected) collections ${ }^{7,12,139}$.

\section{Guidelines}

The greatest discrepancies in the 12 guidelines $6,35,36,43,148$, 157-165 on acute pancreatitis related to the definitions of organ failure and those of predicted severe disease. These are summarized in Table 3.

\section{Discussion}

The present review has demonstrated that the Atlanta definitions of severity and local complications of acute pancreatitis are being used inconsistently, and that several components of the classification have received considerable criticism. By providing definitions, the result of consensus by over 40 experts based on the data available in 1992, the Atlanta symposium improved the management of acute pancreatitis and clinical research relating to the condition. However, the past 20 years have seen not only new insights in pathophysiology and therapeutic strategies but also improved imaging techniques. Clearly, the time has come to revise the classification of acute pancreatitis.

The various predictive scoring systems have not improved substantially since the Atlanta symposium. They are only moderately accurate in predicting severe disease in an individual patient. As McKay and Imrie ${ }^{166}$ have noted, predictive systems were developed initially to allocate patients within clinical trials and not to assess severity in an individual. Defining severity based on the presence or absence of organ failure also has its limitations. It is increasingly recognized that persistent organ failure (for more than $48 \mathrm{~h}$ ) is the most important determinant of morbidity and mortality, which are predominantly related to the number of organ systems failing, the degree of dysfunction of the organs involved and the duration of organ failure.

The definition of necrotizing pancreatitis is controversial because it incorporates both sterile and infected necrosis, and covers both pancreatic parenchymal necrosis and peripancreatic fat necrosis. Interpretations of pseudocyst and pancreatic abscess vary widely because necrotic debris within these collections is often not accounted for. This might be explained by the incapacity of CECT to detect necrotic debris in collections predominantly containing fluid, and its incapacity to discriminate between sterile and infected collections ${ }^{7,10,12,92,167}$. Although magnetic resonance imaging (MRI) and (endoscopic) ultrasonography may be of additional value in classifying these collections ${ }^{10,168,169}$, their applicability in severely ill patients has been questioned ${ }^{92,170}$.

Although the Atlanta Classification incorporates a pathological and morphological description of different local complications, it does not provide exact radiological criteria for each. The recently demonstrated poor interobserver agreement on the Atlanta Classification of local complications ${ }^{8}$ highlights the need for new descriptive morphological terms to describe CECT findings. The existing radiological grading system, the CT severity index, is a numerical scoring system that combines quantification of extrapancreatic changes with the extent of pancreatic necrosis ${ }^{26}$. Although the CT severity index has clear prognostic value with regard to morbidity and mortality ${ }^{26,171-174}$, it does not characterize the local complications of acute pancreatitis.

Much of the persisting controversy over the natural course of (peri)pancreatic collections is due to a lack of prospective data from large patient series. The authors of this review, therefore, advocate a collaborative international study to clarify pathophysiology, natural course and optimal management of (peri)pancreatic 
collections. The present review has aimed to give an overview of the controversies regarding the Atlanta Classification in the literature. There are virtually no studies addressing the validation of the definitions proposed by the Atlanta Classification. Consequently, hardly any original data on this topic are available to analyse. This review, therefore, has merely categorized applications and interpretations of the Atlanta definitions. Correct terminology and standardized definitions are important for adequate communication in clinical practice and for comparing interinstitutional data for clinical research. The continuing failure to use standardized definitions for predicted and actual severe acute pancreatitis, organ failure and the local complications, and the heterogeneity of inclusion criteria of patients in clinical trials, have hampered the progress of evidence-based recommendations. This review has identified many studies that have improved insight into the natural course of the disease. These new insights should be used to design a new classification.

The authors propose the following recommendations for revision of the classification of acute pancreatitis. First, the diagnosis should incorporate two of the following three items: upper abdominal pain, amylase and/or lipase levels at least three times the upper limit of normal (as this cutoff is used most frequently in the literature), and CT or MRI findings compatible with acute pancreatitis. Second, persistent organ failure (for at least $48 \mathrm{~h}$ ) should have an important role in defining severity of acute pancreatitis. Third, it should be decided which predictive scoring system(s), including cut-off value, should be used to define predicted severe acute pancreatitis, based on a systematic review of the available data. Fourth, future studies should always make a clear distinction between predicted severe and actual severe disease, with a posteriori validation of the disease severity. Fifth, a systematic review should demonstrate which organ failure scoring system should be used, and definitions for organ failure should take into account the number of organ systems failing, the duration (less or more than $48 \mathrm{~h}$ ) of organ failure, and the need for specific therapy (such as inotropic or vasopressor agents, mechanical ventilation and dialysis). Sixth, peripancreatic fat necrosis without pancreatic parenchymal necrosis should be regarded either as a separate entity or as necrotizing pancreatitis. Seventh, infected necrosis should be regarded as a separate entity. Eighth, a term should be appointed for encapsulated collections containing both fluid and necrotic debris. Ninth, in order to diagnose a collection that contains fluid only (such as pseudocyst), MRI or (endoscopic) ultrasonography should be performed first to exclude necrotic debris in the collection. Tenth, a new set of descriptive morphological terms should be designed to describe local complications on CT.

Such a new classification system should be evaluated in high-quality interobserver and prospective clinical studies. Adjustments should be made every few years, based on new data. Most importantly, clinicians and radiologists worldwide should comply with the new classification in clinical practice and research. Progress in the field of acute pancreatitis is hampered greatly when various author groups use their own idiosyncratic definitions. When journal referees are requested to peer-review manuscripts, they should pay special attention to the correct use of definitions as defined by a new classification.

\section{Acknowledgements}

The authors thank Michael G. Sarr and Louis M. A. Akkermans for their support and critical review of a previous version of the manuscript.

\section{References}

1 Sarles H. Proposal adopted unanimously by the participants of the Symposium, Marseille 1963. Bibl Gastroenterol 1965; 7: 7-8.

2 Sarner M, Cotton PB. Classification of pancreatitis. Gut 1984; 25: 756-759.

3 Singer MV, Gyr K, Sarles H. Revised classification of pancreatitis. Report of the Second International Symposium on the Classification of Pancreatitis in Marseille, France, March 28-30, 1984. Gastroenterology 1985; 89: 683-685.

4 Bradley EL III. A clinically based classification system for acute pancreatitis. Summary of the International Symposium on Acute Pancreatitis, Atlanta, Ga, September 11 through 13, 1992. Arch Surg 1993; 128: 586-590.

5 Bradley EL III. A clinically based classification system for acute pancreatitis. Ann Chir 1993; 47: 537-541.

6 Banks PA, Freeman ML, the Practice Parameters Committee of the American College of Gastroenterology (2006). Practice guidelines in acute pancreatitis. Am $\mathcal{F}$ Gastroenterol 2006; 101: 2379-2400.

7 Baron TH, Morgan DE, Vickers SM, Lazenby AJ. Organized pancreatic necrosis: endoscopic, radiologic, and pathologic features of a distinct clinical entity. Pancreas 1999; 19: 105-108.

8 Besselink MG, van Santvoort HC, Bollen TL, van Leeuwen MS, Lameris JS, van der Jagt EJ et al. Describing computed tomography findings in acute necrotizing pancreatitis with the Atlanta classification: an interobserver agreement study. Pancreas 2006; 33: 331-335.

9 Dervenis C, Bassi C. Evidence-based assessment of severity and management of acute pancreatitis. Br 7 Surg 2000; 87: $257-258$. 
10 Morgan DE, Baron TH, Smith JK, Robbin ML, Kenney PJ. Pancreatic fluid collections prior to intervention: evaluation with MR imaging compared with CT and US. Radiology 1997; 203: 773-778.

11 Papachristou GI, Papachristou DJ, Avula H, Slivka A, Whitcomb DC. Obesity increases the severity of acute pancreatitis: performance of APACHE-O score and correlation with the inflammatory response. Pancreatology 2006; 6: 279-285.

12 Petrakis I, Vrachassotakis N, Kogerakis N, Koutsoumpas V, Chalkiadakis G. Subacute pancreatic necrosis. Panminerva Med 2000; 42: 279-286.

13 Vege SS, Chari ST. Organ failure as an indicator of severity of acute pancreatitis: time to revisit the Atlanta classification. Gastroenterology 2005; 128: 1133-1135.

14 Bollen TL, Besselink MG, Van Santvoort HC, Gooszen HG, Van Leeuwen MS. Towards an update of the Atlanta classification on acute pancreatitis: review of new and abandoned terms. Pancreas 2007; 35: 107-113.

15 Acosta JM, Katkhouda N, Debian KA, Groshen SG, Tsao-Wei DD, Berne TV. Early ductal decompression versus conservative management for gallstone pancreatitis with ampullary obstruction: a prospective randomized clinical trial. Ann Surg 2006; 243: 33-40.

16 Garg PK, Madan K, Pande GK, Khanna S, Sathyanarayan G, Bohidar NP et al. Association of extent and infection of pancreatic necrosis with organ failure and death in acute necrotizing pancreatitis. Clin Gastroenterol Hepatol 2005; 3: 159-166.

17 Hofner P, Balog A, Gyulai Z, Farkas G, Rakonczay Z, Takacs $T$ et al. Polymorphism in the IL-8 gene, but not in the TLR4 gene, increases the severity of acute pancreatitis. Pancreatology 2006; 6: 542-548.

18 McKay CJ, Curran F, Sharples C, Baxter JN, Imrie CW. Prospective placebo-controlled randomized trial of lexipafant in predicted severe acute pancreatitis. Br 7 Surg 1997; 84: 1239-1243.

19 Mery CM, Rubio V, Duarte-Rojo A, Suazo-Barahona J, Pelaez-Luna M, Milke P et al. Android fat distribution as predictor of severity in acute pancreatitis. Pancreatology 2002; 2: 543-549.

20 Murray B, Carter R, Imrie C, Evans S, O'Suilleabhain C. Diclofenac reduces the incidence of acute pancreatitis after endoscopic retrograde cholangiopancreatography. Gastroenterology 2003; 124: 1786-1791.

21 Masci E, Cavallini G, Mariani A, Frulloni L, Testoni PA, Curioni $\mathrm{S}$ et al. Comparison of two dosing regimens of gabexate in the prophylaxis of post-ERCP pancreatitis. $\mathrm{Am}$ 7 Gastroenterol 2003; 98: 2182-2186.

22 Rahman SH, Ibrahim K, Larvin M, Kingsnorth A, McMahon MJ. Association of antioxidant enzyme gene polymorphisms and glutathione status with severe acute pancreatitis. Gastroenterology 2004; 126: 1312-1322.

23 Remes-Troche JM, Uscanga LF, Pelaez-Luna M, Duarte-Rojo A, Gonzalez-Balboa P, Teliz MA et al. When should we be concerned about pancreatic necrosis? Analysis from a single institution in Mexico City. World 7 Surg 2006; 30: $2227-2233$.

24 Martinez J, Johnson CD, Sanchez-Paya J, de Madaria E, Robles-Diaz G, Perez-Mateo M. Obesity is a definitive risk factor of severity and mortality in acute pancreatitis: an updated meta-analysis. Pancreatology 2006; 6: 206-209.

25 Stimac D, Fisic E, Milic S, Bilic-Zulle L, Peric R. Prognostic values of IL- 6 , IL- 8 , and IL-10 in acute pancreatitis. F Clin Gastroenterol 2006; 40: 209-212.

26 Balthazar EJ, Robinson DL, Megibow AJ, Ranson JH. Acute pancreatitis: value of CT in establishing prognosis. Radiology 1990; 174: 331-336.

27 Ju S, Chen F, Liu S, Zheng K, Teng G. Value of CT and clinical criteria in assessment of patients with acute pancreatitis. Eur F Radiol 2006; 57: 102-107.

28 Kumar A, Singh N, Prakash S, Saraya A, Joshi YK. Early enteral nutrition in severe acute pancreatitis: a prospective randomized controlled trial comparing nasojejunal and nasogastric routes. 7 Clin Gastroenterol 2006; 40: 431-434.

29 Leung TK, Lee CM, Lin SY, Chen HC, Wang HJ, Shen LK et al. Balthazar computed tomography severity index is superior to Ranson criteria and APACHE II scoring system in predicting acute pancreatitis outcome. World $\mathcal{F}$ Gastroenterol 2005; 11: 6049-6052.

30 Modrau IS, Floyd AK, Thorlacius-Ussing O. The clinical value of procalcitonin in early assessment of acute pancreatitis. Am f Gastroenterol 2005; 100: 1593-1597.

31 Mofidi R, Duff MD, Wigmore SJ, Madhavan KK, Garden OJ, Parks RW. Association between early systemic inflammatory response, severity of multiorgan dysfunction and death in acute pancreatitis. Br F Surg 2006; 93 : 738-744.

32 Taylor SL, Morgan DL, Denson KD, Lane MM, Pennington LR. A comparison of the Ranson, Glasgow, and APACHE II scoring systems to a multiple organ system score in predicting patient outcome in pancreatitis. $A m \mathcal{F}$ Surg 2005; 189: 219-222.

33 Nealon WH, Bawduniak J, Walser EM. Appropriate timing of cholecystectomy in patients who present with moderate to severe gallstone-associated acute pancreatitis with peripancreatic fluid collections. Ann Surg 2004; 239: 741-749.

34 Runzi M, Niebel W, Goebell H, Gerken G, Layer P. Severe acute pancreatitis: nonsurgical treatment of infected necroses. Pancreas 2005; 30: 195-199.

35 Toouli J, Brooke-Smith M, Bassi C, Carr-Locke D, Telford J, Freeny $\mathrm{P}$ et al. Guidelines for the management of acute pancreatitis. 7 Gastroenterol Hepatol 2002; 17(Suppl): S15-S39.

36 French Consensus Conference on Acute Pancreatitis: Conclusions and Recommendations. Paris, France, 25-26 January 2001. Eur 7 Gastroenterol Hepatol 2001; 13(Suppl 4): S1-S13.

37 Martinez J, Sanchez-Paya J, Palazon JM, Aparicio JR, Pico A, Perez-Mateo M. Obesity: a prognostic factor of severity in acute pancreatitis. Pancreas 1999; 19: 15-20. 
38 Heller SJ, Noordhoek E, Tenner SM, Ramagopal V, Abramowitz M, Hughes $M$ et al. Pleural effusion as a predictor of severity in acute pancreatitis. Pancreas 1997; 15: $222-225$.

39 Talamini G, Bassi C, Falconi M, Sartori N, Frulloni L, Di Francesco $\mathrm{V}$ et al. Risk of death from acute pancreatitis. Role of early, simple 'routine' data. Int 7 Pancreatol 1996; 19: $15-24$.

40 Talamini G, Uomo G, Pezzilli R, Rabitti PG, Billi P, Bassi $\mathrm{C}$ et al. Serum creatinine and chest radiographs in the early assessment of acute pancreatitis. Am $\mathcal{F}$ Surg 1999; 177: $7-14$.

41 Brown A, Orav J, Banks PA. Hemoconcentration is an early marker for organ failure and necrotizing pancreatitis. Pancreas 2000; 20: 367-372.

42 Brown A, Baillargeon JD, Hughes MD, Banks PA. Can fluid resuscitation prevent pancreatic necrosis in severe acute pancreatitis? Pancreatology 2002; 2: 104-107.

43 UK Working Party on Acute Pancreatitis. UK guidelines for the management of acute pancreatitis. Gut 2005; 54(Suppl 3): iii1-iii9.

44 Robert JH, Frossard JL, Mermillod B, Soravia C, Mensi N, Roth $\mathrm{M}$ et al. Early prediction of acute pancreatitis: prospective study comparing computed tomography scans, Ranson, Glasgow, Acute Physiology And Chronic Health Evaluation II scores, and various serum markers. World 7 Surg 2002; 26: 612-619.

45 Yadav D, Agarwal N, Pitchumoni CS. A critical evaluation of laboratory tests in acute pancreatitis. Am 7 Gastroenterol 2002; 97: 1309-1318.

46 Eckerwall GE, Axelsson JB, Andersson RG. Early nasogastric feeding in predicted severe acute pancreatitis: a clinical, randomized study. Ann Surg 2006; 244: 959-965.

47 Manes G, Uomo I, Menchise A, Rabitti PG, Ferrara EC, Uomo G. Timing of antibiotic prophylaxis in acute pancreatitis: a controlled randomized study with meropenem. Am $\mathcal{F}$ Gastroenterol 2006; 101: 1348-1353.

48 Nagpal K, Minocha VR, Agrawal V, Kapur S. Evaluation of intestinal mucosal permeability function in patients with acute pancreatitis. Am 7 Surg 2006; 192: 24-28.

49 Andersson B, Olin H, Eckerwall G, Andersson R. Severe acute pancreatitis - outcome following a primarily non-surgical regime. Pancreatology 2006; 6: 536-541.

50 Ishikawa K, Idoguchi K, Tanaka H, Tohma Y, Ukai I, Watanabe $\mathrm{H}$ et al. Classification of acute pancreatitis based on retroperitoneal extension: application of the concept of interfascial planes. Eur 7 Radiol 2006; 60: 445-452.

51 Rau B, Bothe A, Beger HG. Surgical treatment of necrotizing pancreatitis by necrosectomy and closed lavage: changing patient characteristics and outcome in a 19-year, single-center series. Surgery 2005; 138: 28-39.

52 Rau BM, Bothe A, Kron M, Beger HG. Role of early multisystem organ failure as major risk factor for pancreatic infections and death in severe acute pancreatitis. Clin Gastroenterol Hepatol 2006; 4: 1053-1061.
53 Lankisch PG, Pflichthofer D, Lehnick D. No strict correlation between necrosis and organ failure in acute pancreatitis. Pancreas 2000; 20: 319-322.

54 Wiesner W, Studler U, Kocher T, Degen L, Buitrago-Tellez CH, Steinbrich W. Colonic involvement in non-necrotizing acute pancreatitis: correlation of CT findings with the clinical course of affected patients. Eur Radiol 2003; 13: 897-902.

55 Ashley SW, Perez A, Pierce EA, Brooks DC, Moore FD Jr, Whang EE et al. Necrotizing pancreatitis: contemporary analysis of 99 consecutive cases. Ann Surg 2001; 234: $572-579$.

56 Company L, Saez J, Martinez J, Aparicio JR, Laveda R, Grino $\mathrm{P}$ et al. Factors predicting mortality in severe acute pancreatitis. Pancreatology 2003; 3: 144-148.

57 Tenner S. Initial management of acute pancreatitis: critical issues during the first 72 hours. Am 7 Gastroenterol 2004; 99 : 2489-2494.

58 Gloor B, Muller CA, Worni M, Martignoni ME, Uhl W, Buchler MW. Late mortality in patients with severe acute pancreatitis. Br J Surg 2001; 88: 975-979.

59 Gotzinger P, Sautner T, Kriwanek S, Beckerhinn P, Barlan M, Armbruster C et al. Surgical treatment for severe acute pancreatitis: extent and surgical control of necrosis determine outcome. World 7 Surg 2002; 26: 474-478.

60 Eatock FC, Chong P, Menezes N, Murray L, McKay CJ, Carter CR et al. A randomized study of early nasogastric versus nasojejunal feeding in severe acute pancreatitis. Am $\mathcal{F}$ Gastroenterol 2005; 100: 432-439.

61 Berzin TM, Mortele KJ, Banks PA. The management of suspected pancreatic sepsis. Gastroenterol Clin North Am 2006; 35: 393-407.

62 De Waele B, Vanmierlo B, Van Nieuwenhove Y, Delvaux G. Impact of body overweight and class I, II and III obesity on the outcome of acute biliary pancreatitis. Pancreas 2006; 32: 343-345.

63 Halonen KI, Leppaniemi AK, Lundin JE, Puolakkainen PA, Kemppainen EA, Haapiainen RK. Predicting fatal outcome in the early phase of severe acute pancreatitis by using novel prognostic models. Pancreatology 2003; 3: 309-315.

64 Kylanpaa-Back ML, Takala A, Kemppainen EA, Puolakkainen PA, Leppaniemi AK, Karonen SL et al. Procalcitonin, soluble interleukin-2 receptor, and soluble E-selectin in predicting the severity of acute pancreatitis. Crit Care Med 2001; 29: 63-69.

65 Mentula P, Kylanpaa ML, Kemppainen E, Jansson SE, Sarna S, Puolakkainen P et al. Early prediction of organ failure by combined markers in patients with acute pancreatitis. Br 7 Surg 2005; 92: 68-75.

66 Maeda K, Hirota M, Ichihara A, Ohmuraya M, Hashimoto D, Sugita H et al. Applicability of disseminated intravascular coagulation parameters in the assessment of the severity of acute pancreatitis. Pancreas 2006; 32: 87-92.

67 Besselink MG, van Santvoort HC, Nieuwenhuijs VB, Boermeester MA, Bollen TL, Buskens E et al. Minimally invasive 'step-up approach' versus maximal necrosectomy in 
patients with acute necrotising pancreatitis (PANTER trial): design and rationale of a randomised controlled multicenter trial [ISRCTN38327949]. BMC Surg 2006; 6: 6.

68 Dauphine C, Kovar J, Stabile BE, Haukoos JS, de Virgilio C. Identification of admission values predictive of complicated acute alcoholic pancreatitis. Arch Surg 2004; 139: 978-982.

69 Rau B, Baumgart K, Kruger CM, Schilling M, Beger HG. CC-chemokine activation in acute pancreatitis: enhanced release of monocyte chemoattractant protein-1 in patients with local and systemic complications. Intensive Care Med 2003; 29: 622-629.

70 Buter A, Imrie CW, Carter CR, Evans S, McKay CJ. Dynamic nature of early organ dysfunction determines outcome in acute pancreatitis. Br 7 Surg 2002; 89: 298-302.

71 Flint R, Windsor JA. Early physiological response to intensive care as a clinically relevant approach to predicting the outcome in severe acute pancreatitis. Arch Surg 2004; 139: $438-443$.

72 Johnson CD, Abu-Hilal M. Persistent organ failure during the first week as a marker of fatal outcome in acute pancreatitis. Gut 2004; 53: 1340-1344.

73 Liu TH, Kwong KL, Tamm EP, Gill BS, Brown SD, Mercer DW. Acute pancreatitis in intensive care unit patients: value of clinical and radiologic prognosticators at predicting clinical course and outcome. Crit Care Med 2003; 31: $1026-1030$.

74 Tao HQ, Zhang JX, Zou SC. Clinical characteristics and management of patients with early acute severe pancreatitis: experience from a medical center in China. World 7 Gastroenterol 2004; 10: 919-921.

75 Pitchumoni CS, Patel NM, Shah P. Factors influencing mortality in acute pancreatitis: can we alter them? 7 Clin Gastroenterol 2005; 39: 798-814.

76 Werner J, Feuerbach S, Uhl W, Buchler MW. Management of acute pancreatitis: from surgery to interventional intensive care. Gut 2005; 54: 426-436.

77 Whitcomb DC. Clinical practice. Acute pancreatitis. N Engl 7 Med 2006; 354: 2142-2150.

78 Ferrucci JT III, Mueller PR. Interventional approach to pancreatic fluid collections. Radiol Clin North Am 2003; 41: 1217-1226, vii.

79 Arvanitakis M, Delhaye M, De Maertelaere V, Bali M, Winant C, Coppens E et al. Computed tomography and magnetic resonance imaging in the assessment of acute pancreatitis. Gastroenterology 2004; 126: 715-723.

80 Scialpi M, Scaglione M, Angelelli G, Lupattelli L, Resta MC, Resta M et al. Emergencies in the retroperitoneum: assessment of spread of disease by helical CT. Eur 7 Radiol 2004; 50: 74-83.

81 Beger HG, Rau B, Isenmann R. Natural history of necrotizing pancreatitis. Pancreatology 2003; 3: 93-101.

82 Neff R. Pancreatic pseudocysts and fluid collections: percutaneous approaches. Surg Clin North Am 2001; 81 : 399-403, xii.
83 Gibbs CM, Baron TH. Outcome following endoscopic transmural drainage of pancreatic fluid collections in outpatients. 7 Clin Gastroenterol 2005; 39: 634-637.

84 Hookey LC, Debroux S, Delhaye M, Arvanitakis M, Le Moine O, Deviere J. Endoscopic drainage of pancreatic-fluid collections in 116 patients: a comparison of etiologies, drainage techniques, and outcomes. Gastrointest Endosc 2006; 63: 635-643.

85 Monkemuller KE, Harewood GC, Curioso WH, Fry LC, Wilcox CM, Morgan DE et al. Biochemical analysis of pancreatic fluid collections predicts bacterial infection. $\mathcal{F}$ Gastroenterol Hepatol 2005; 20: 1667-1673.

86 Traverso LW, Kozarek RA. Pancreatic necrosectomy: definitions and technique. 7 Gastrointest Surg 2005; 9: 436-439.

87 Zhou ZG, Zheng YC, Shu Y, Hu WM, Tian BL, Li QS et al. Laparoscopic management of severe acute pancreatitis. Pancreas 2003; 27: e46-e50.

88 Maringhini A, Uomo G, Patti R, Rabitti P, Termini A, Cavallera A et al. Pseudocysts in acute nonalcoholic pancreatitis: incidence and natural history. Dig Dis Sci 1999; 44: 1669-1673.

89 Soliani P, Franzini C, Ziegler S, Del RP, Dell'Abate P, Piccolo D et al. Pancreatic pseudocysts following acute pancreatitis: risk factors influencing therapeutic outcomes. 7OP 2004; 5: 338-347.

90 De Waele J, Vogelaers D, Decruyenaere J, De Vos M, Colardyn F. Infectious complications of acute pancreatitis. Acta Clin Belg 2004; 59: 90-96.

91 Casas JD, Diaz R, Valderas G, Mariscal A, Cuadras P. Prognostic value of CT in the early assessment of patients with acute pancreatitis. A7R Am 7 Roentgenol 2004; 182: $569-574$.

92 Merkle EM, Gorich J. Imaging of acute pancreatitis. Eur Radiol 2002; 12: 1979-1992.

93 Flint R, Windsor J, Bonham M. Trends in the management of severe acute pancreatitis: interventions and outcome. ANZ 7 Surg 2004; 74: 335-342.

94 Gardner TB, Olenec CA, Chertoff JD, Mackenzie TA, Robertson DJ. Hemoconcentration and pancreatic necrosis: further defining the relationship. Pancreas 2006; 33 : 169-173.

95 Malangoni MA, Martin AS. Outcome of severe acute pancreatitis. Am 7 Surg 2005; 189: 273-277.

96 Papachristou GI, Papachristou DJ, Morinville VD, Slivka A, Whitcomb DC. Chronic alcohol consumption is a major risk factor for pancreatic necrosis in acute pancreatitis. Am 7 Gastroenterol 2006; 101: 2605-2610.

97 Vege SS, Baron TH. Management of pancreatic necrosis in severe acute pancreatitis. Clin Gastroenterol Hepatol 2005; 3 : $192-196$.

98 Howard JM. Acute necrotizing pancreatitis. Hypoperfusion may not be synonymous with gangrene. Int 7 Pancreatol 1997; 22: 233-234. 
99 Traverso LW, Kozarek RA. Interventional management of peripancreatic fluid collections. Surg Clin North Am 1999; 79: 745-757, viii-ix.

100 Takeda K, Matsuno S, Sunamura M, Kakugawa Y. Continuous regional arterial infusion of protease inhibitor and antibiotics in acute necrotizing pancreatitis. Am $\mathcal{F}$ Surg 1996; 171: 394-398.

101 Takeda K, Matsuno S, Ogawa M, Watanabe S, Atomi Y. Continuous regional arterial infusion (CRAI) therapy reduces the mortality rate of acute necrotizing pancreatitis: results of a cooperative survey in Japan. $\mathcal{F}$ Hepatobiliary Pancreat Surg 2001; 8: 216-220.

102 Takeda K, Yamauchi J, Shibuya K, Sunamura M, Mikami Y, Matsuno S. Benefit of continuous regional arterial infusion of protease inhibitor and antibiotic in the management of acute necrotizing pancreatitis. Pancreatology 2001; 1: 668-673.

103 Johnson CD, Stephens DH, Sarr MG. CT of acute pancreatitis: correlation between lack of contrast enhancement and pancreatic necrosis. AfR Am $\mathcal{F}$ Roentgenol 1991; 156: 93-95.

104 Larvin M, Chalmers AG, McMahon MJ. Dynamic contrast enhanced computed tomography: a precise technique for identifying and localising pancreatic necrosis. BM7 1990; 300: $1425-1428$.

105 Runzi M, Raptopoulos V, Saluja AK, Kaiser AM, Nishino H, Gerdes D et al. Evaluation of necrotizing pancreatitis in the opossum by dynamic contrast-enhanced computed tomography: correlation between radiographic and morphologic changes. 7 Am Coll Surg 1995; 180: 673-682.

106 Balthazar EJ. Acute pancreatitis: assessment of severity with clinical and CT evaluation. Radiology 2002; 223: 603-613.

107 Martin DR, Karabulut N, Yang M, McFadden DW. High signal peripancreatic fat on fat-suppressed spoiled gradient echo imaging in acute pancreatitis: preliminary evaluation of the prognostic significance. 7 Magn Reson Imaging 2003; 18: 49-58.

108 Bradley EL III. A fifteen year experience with open drainage for infected pancreatic necrosis. Surg Gynecol Obstet 1993; 177: 215-222.

109 Gambiez LP, Denimal FA, Porte HL, Saudemont A, Chambon JP, Quandalle PA. Retroperitoneal approach and endoscopic management of peripancreatic necrosis collections. Arch Surg 1998; 133: 66-72.

110 Forsmark CE. The clinical problem of biliary acute necrotizing pancreatitis: epidemiology, pathophysiology, and diagnosis of biliary necrotizing pancreatitis. 7 Gastrointest Surg 2001; 5: 235-239.

111 Gan I, May G, Raboud J, Tilley J, Enns R. Pancreatitis in $\mathrm{HIV}$ infection: predictors of severity. Am 7 Gastroenterol 2003; 98: 1278-1283.

112 Papachristou GI, Whitcomb DC. Predictors of severity and necrosis in acute pancreatitis. Gastroenterol Clin North Am 2004; 33: 871-890.
113 Beger HG, Bittner R, Block S, Buchler M. Bacterial contamination of pancreatic necrosis. A prospective clinical study. Gastroenterology 1986; 91: 433-438.

114 Hartwig W, Werner J, Muller CA, Uhl W, Buchler MW. Surgical management of severe pancreatitis including sterile necrosis. 7 Hepatobiliary Pancreat Surg 2002; 9: 429-435.

115 Le Mée J, Paye F, Sauvanet A, O’Toole D, Hammel P, Marty $\mathrm{J}$ et al. Incidence and reversibility of organ failure in the course of sterile or infected necrotizing pancreatitis. Arch Surg 2001; 136: 1386-1390.

116 Freeny PC, Hauptmann E, Althaus SJ, Traverso LW, Sinanan M. Percutaneous CT-guided catheter drainage of infected acute necrotizing pancreatitis: techniques and results. A7R Am F Roentgenol 1998; 170: 969-975.

117 Memis A, Parildar M. Interventional radiological treatment in complications of pancreatitis. Eur 7 Radiol 2002; 43: 219-228.

118 Mortele KJ, Banks PA, Silverman SG. State-of-the-art imaging of acute pancreatitis. FBR-BTR 2003; 86: 193-208.

119 Kingsnorth A, O'Reilly D. Acute pancreatitis. BMF 2006; 332: 1072-1076.

120 Nealon WH, Walser E. Surgical management of complications associated with percutaneous and/or endoscopic management of pseudocyst of the pancreas. Ann Surg 2005; 241: 948-957.

121 Kruger M, Schneider AS, Manns MP, Meier PN. Endoscopic management of pancreatic pseudocysts or abscesses after an EUS-guided 1-step procedure for initial access. Gastrointest Endosc 2006; 63: 409-416.

122 Andren-Sandberg A, Ansorge C, Eiriksson K, Glomsaker T, Maleckas A. Treatment of pancreatic pseudocysts. Scand 7 Surg 2005; 94: 165-175.

123 Baron TH. Endoscopic drainage of pancreatic fluid collections and pancreatic necrosis. Gastrointest Endosc Clin NAm 2003; 13: 743-764.

124 Hawes RH. Endoscopic management of pseudocysts. Rev Gastroenterol Disord 2003; 3: 135-141.

125 Baron TH, Harewood GC, Morgan DE, Yates MR. Outcome differences after endoscopic drainage of pancreatic necrosis, acute pancreatic pseudocysts, and chronic pancreatic pseudocysts. Gastrointest Endosc 2002; 56: 7-17.

126 Beckingham IJ, Krige JE, Bornman PC, Terblanche J. Long term outcome of endoscopic drainage of pancreatic pseudocysts. Am 7 Gastroenterol 1999; 94: 71-74.

127 Bradley EL III. Atlanta redux. Pancreas 2003; 26: 105-106.

128 Baillie J. Pancreatic pseudocysts (Part II). Gastrointest Endosc 2004; 60: 105-113.

129 Oria A, Ocampo C, Zandalazini H, Chiappetta L, Moran C. Internal drainage of giant acute pseudocysts: the role of video-assisted pancreatic necrosectomy. Arch Surg 2000; 135: $136-140$.

130 Andren-Sandberg A, Dervenis C. Pancreatic pseudocysts in the 21 st century. Part I: classification, pathophysiology, anatomic considerations and treatment. 7OP 2004; 5: 8-24.

131 Soliani P, Ziegler S, Franzini C, Dell'Abate P, Del Rio P, Di Mario F et al. The size of pancreatic pseudocyst does not 
influence the outcome of invasive treatments. Dig Liver Dis 2004; 36: 135-140.

132 Bhasin DK, Rana SS, Udawat HP, Thapa BR, Sinha SK, Nagi B. Management of multiple and large pancreatic pseudocysts by endoscopic transpapillary nasopancreatic drainage alone. Am 7 Gastroenterol 2006; 101: 1780-1786.

133 Kahaleh M, Shami VM, Conaway MR, Tokar J, Rockoff T, De La Rue SA et al. Endoscopic ultrasound drainage of pancreatic pseudocyst: a prospective comparison with conventional endoscopic drainage. Endoscopy 2006; 38 : $355-359$

134 Seewald S, Groth S, Omar S, Imazu H, Seitz U, de Weerth A et al. Aggressive endoscopic therapy for pancreatic necrosis and pancreatic abscess: a new safe and effective treatment algorithm (videos). Gastrointest Endosc 2005; 62: 92-100.

135 Srikanth G, Sikora SS, Baijal SS, Ayyagiri A, Kumar A, Saxena $\mathrm{R}$ et al. Pancreatic abscess: 10 years experience. $A N Z$ 7 Surg 2002; 72: 881-886.

136 Venu RP, Brown RD, Marrero JA, Pastika BJ, Frakes JT. Endoscopic transpapillary drainage of pancreatic abscess: technique and results. Gastrointest Endosc 2000; 51: 391-395.

137 Baril NB, Ralls PW, Wren SM, Selby RR, Radin R, Parekh D et al. Does an infected peripancreatic fluid collection or abscess mandate operation? Ann Surg 2000; 231: $361-367$.

138 Haan JM, Scalea TM. Laparoscopic debridement of recurrent pancreatic abscesses in the hostile abdomen. $\mathrm{Am}$ Surg 2006; 72: 511-514.

139 Park JJ, Kim SS, Koo YS, Choi DJ, Park HC, Kim JH et al. Definitive treatment of pancreatic abscess by endoscopic transmural drainage. Gastrointest Endosc 2002; 55: 256-262.

140 Howard TJ, Wiebke EA, Mogavero G, Kopecky K, Baer JC, Sherman S et al. Classification and treatment of local septic complications in acute pancreatitis. Am 7 Surg 1995; 170: 44-50.

141 Giovannini M, Pesenti C, Rolland AL, Moutardier V, Delpero JR. Endoscopic ultrasound-guided drainage of pancreatic pseudocysts or pancreatic abscesses using a therapeutic echo endoscope. Endoscopy 2001; 33: 473-477.

142 van Sonnenberg E, Wittich GR, Chon KS, D'Agostino HB, Casola G, Easter D et al. Percutaneous radiologic drainage of pancreatic abscesses. AfR Am $\mathcal{F}$ Roentgenol 1997; 168: 979-984.

143 Paspulati RM. Multidetector CT of the pancreas. Radiol Clin North Am 2005; 43: 999-1020, viii.

144 Maher MM, Lucey BC, Gervais DA, Mueller PR. Acute pancreatitis: the role of imaging and interventional radiology. Cardiovasc Intervent Radiol 2004; 27: 208-225.

145 Charnley RM, Lochan R, Gray H, O'Sullivan CB, Scott J, Oppong KE. Endoscopic necrosectomy as primary therapy in the management of infected pancreatic necrosis. Endoscopy 2006; 38: 925-928.

146 Beger HG, Rau B, Mayer J, Pralle U. Natural course of acute pancreatitis. World 7 Surg 1997; 21: 130-135.
147 Beger HG, Rau B, Isenmann R, Schwarz M, Gansauge F, Poch B. Antibiotic prophylaxis in severe acute pancreatitis. Pancreatology 2005; 5: 10-19.

148 Nathens AB, Curtis JR, Beale RJ, Cook DJ, Moreno RP, Romand JA et al. Management of the critically ill patient with severe acute pancreatitis. Crit Care Med 2004; 32 : 2524-2536.

149 Balthazar EJ, Freeny PC, van Sonnenberg E. Imaging and intervention in acute pancreatitis. Radiology 1994; 193 : 297-306.

150 Tsiotos GG, Sarr MG. Management of fluid collections and necrosis in acute pancreatitis. Curr Gastroenterol Rep 1999; 1: 139-144.

151 Balthazar EJ. Complications of acute pancreatitis: clinical and CT evaluation. Radiol Clin North Am 2002; 40: $1211-1227$.

152 Carmona-Sanchez R, Uscanga L, Bezaury-Rivas P, Robles-Diaz G, Suazo-Barahona J, Vargas-Vorackova F. Potential harmful effect of iodinated intravenous contrast medium on the clinical course of mild acute pancreatitis. Arch Surg 2000; 135: 1280-1284.

153 Mithofer K, Mueller PR, Warshaw AL. Interventional and surgical treatment of pancreatic abscess. World 7 Surg 1997; 21: $162-168$.

154 Walser EM, Nealon WH, Marroquin S, Raza S, Hernandez JA, Vasek J. Sterile fluid collections in acute pancreatitis: catheter drainage versus simple aspiration. Cardiovasc Intervent Radiol 2006; 29: 102-107.

155 Howard JM, Wagner SM. Pancreatography after recovery from massive pancreatic necrosis. Ann Surg 1989; 209: $31-35$.

156 Cheung MT, Ho CN, Siu KW, Kwok PC. Percutaneous drainage and necrosectomy in the management of pancreatic necrosis. ANZ 7 Surg 2005; 75: 204-207.

157 Banks PA. Practice guidelines in acute pancreatitis. Am 7 Gastroenterol 1997; 92: 377-386.

158 British Society of Gastroenterology. United Kingdom guidelines for the management of acute pancreatitis. Gut 1998; 42(Suppl 2): S1-S13.

159 The Society for Surgery of the Alimentary Tract Patient Care Committee. Treatment of acute pancreatitis. $\mathcal{F}$ Gastrointest Surg 1998; 2: 487-488.

160 Dervenis C, Johnson CD, Bassi C, Bradley E, Imrie CW, McMahon MJ et al. Diagnosis, objective assessment of severity, and management of acute pancreatitis. Santorini consensus conference. Int 7 Pancreatol 1999; 25: 195-210.

161 Uhl W, Warshaw A, Imrie C, Bassi C, McKay CJ, Lankisch PG et al. IAP guidelines for the surgical management of acute pancreatitis. Pancreatology 2002; 2: $565-573$.

162 Mayumi T, Ura H, Arata S, Kitamura N, Kiriyama I, Shibuya K et al. Evidence-based clinical practice guidelines for acute pancreatitis: proposals. 7 Hepatobiliary Pancreat Surg 2002; 9: 413-422.

163 Task Force of the American College of Critical Care Medicine, Society of Critical Care Medicine. Guidelines for 
intensive care unit admission, discharge, and triage. Crit Care Med 1999; 27: 633-638.

164 Hirota M, Takada T, Kawarada Y, Hirata K, Mayumi T, Yoshida $\mathrm{M}$ et al. JPN guidelines for the management of acute pancreatitis: severity assessment of acute pancreatitis. 7 Hepatobiliary Pancreat Surg 2006; 13: 33-41.

165 Sekimoto M, Takada T, Kawarada Y, Hirata K, Mayumi T, Yoshida $\mathrm{M}$ et al. JPN guidelines for the management of acute pancreatitis: epidemiology, etiology, natural history, and outcome predictors in acute pancreatitis. 7 Hepatobiliary Pancreat Surg 2006; 13: 10-24.

166 McKay CJ, Imrie CW. Staging of acute pancreatitis. Is it important? Surg Clin North Am 1999; 79: 733-743.

167 Chalmers AG. The role of imaging in acute pancreatitis. Eur 7 Gastroenterol Hepatol 1997; 9: 106-116.

168 Brugge WR. Evaluation of pancreatic cystic lesions with EUS. Gastrointest Endosc 2004; 59: 698-707.

169 Yusuf TE, Baron TH. Endoscopic transmural drainage of pancreatic pseudocysts: results of a national and an international survey of ASGE members. Gastrointest Endosc 2006; 63: 223-227.
170 Robinson PJ, Sheridan MB. Pancreatitis: computed tomography and magnetic resonance imaging. Eur Radiol 2000; 10: 401-408.

171 Chatzicostas C, Roussomoustakaki M, Vardas E, Romanos J, Kouroumalis EA. Balthazar computed tomography severity index is superior to Ranson criteria and APACHE II and III scoring systems in predicting acute pancreatitis outcome. 7 Clin Gastroenterol 2003; 36: 253-260.

172 Mortele KJ, Wiesner W, Intriere L, Shankar S, Zou KH, Kalantari BN et al. A modified CT severity index for evaluating acute pancreatitis: improved correlation with patient outcome. A7R Am f Roentgenol 2004; 183: 1261-1265.

173 Simchuk EJ, Traverso LW, Nukui Y, Kozarek RA. Computed tomography severity index is a predictor of outcomes for severe pancreatitis. Am $\mathcal{F}$ Surg 2000; 179: $352-355$.

174 Vriens PW, van de Linde P, Slotema ET, Warmerdam PE, Breslau PJ. Computed tomography severity index is an early prognostic tool for acute pancreatitis. 7 Am Coll Surg 2005; 201: 497-502. 